\title{
Albumin in Management of Neonatal Hyperbilirubinaemia
}

\author{
Y. C. TSAO and VICTOR Y. H. YU \\ From the Department of Paediatrics, University of Hong Kong
}

\begin{abstract}
Tsao, Y. C., and Yu, V. Y. H. (1972). Archives of Disease in Childhood, 47, 250. Albumin in management of neonatal hyperbilirubinaemia. The effect of albumin priming on the plasma volume, intravascular bilirubin, and HBABAbinding capacity during the subsequent 2 to $4 \frac{1}{2}$ hours before exchange transfusion was studied in 7 jaundiced neonates with no haemolytic disease. After priming with albumin at a dose of $1.75 \mathrm{~g} / \mathrm{kg}$ body weight as a $10 \%$ solution, there was a marked increase in plasma volume as well as total intravascular bilirubin and HBABAbinding capacity. However, the serum bilirubin concentration fluctuated only very slightly, largely because of the dilution effect of the expanded plasma volume. Both albumin and bilirubin gradually diffused out of the intravascular compartment again, but at the end of the observation period there was still a net gain of both.

In another 20 neonates, the efficiency of exchange transfusion in removing bilirubin was compared. The efficiency was decreased by early albumin priming and enhanced by enriching the donor's blood with albumin.

It is concluded that albumin offers immediate and short-term protection against bilirubin toxicity, and albumin-priming should be useful in situations where the babies are admitted with high bilirubin levels and blood is not immediately available for exchange transfusion. Because of its effect on the plasma volume, albumin is not recommended for babies who are already hypervolaemic. If albumin is used to increase the efficiency of exchange transfusion, it should be given together with donor's blood or shortly before the procedure.
\end{abstract}

Bilirubin exists in human plasma largely bound to albumin (Ostrow and Schmid, 1963). Only a small amount is present in the free or diffusible form (Odell, 1959a; Burnstine and Schmid, 1962). It is the latter fraction which determines its toxicity. Many factors, such as $\mathrm{pH}$, ionic concentration, and the presence of organic anions that compete with bilirubin for the binding site, can influence the dissociation of the albumin-bilirubin complex (Harris, Lucey, and MacLean, 1958; Odell, 1959b, 1970). However, given the same conditions, an increased amount of albumin is protective against bilirubin toxicity by providing more binding sites, thereby reducing the level of free bilirubin. Furthermore, though crystalline albumin is capable of binding bilirubin up to molar ratio of $1: 2$ at $p \mathrm{H}$ $7 \cdot 4$ the first molecule of bilirubin is more tightly bound to albumin than the second molecule

Received 6 October 1971.
(Odell, 1959a) and the binding capacity of plasma albumin is already much reduced because of the presence of other organic anions.

Albumin has been used to raise the serum albumin level in premature babies (Odell, 1959a), and in association with exchange transfusion to increase bilirubin removal (Kitchen, Krieger, and Smith, 1960; Odell, Cohen, and Gordes, 1962; Comley and Wood, 1968). In situations where the neonate is admitted with high serum bilirubin level and when blood is not readily available for exchange transfusion, albumin may offer protection against kernicterus, and may even extract bilirubin which has already diffused into the tissues (Diamond and Schmid, 1966). Odell (1959a) found that the administration of albumin to babies with hyperbilirubinaemia caused a rise in the level of serum bilirubin, and therefore reasoned that the efficiency of bilirubin removal would be increased thereby. Other workers (Lucey, 1966; Diamond, 1969) 
expressed caution that such rise in serum bilirubin level would remove one of the main danger signals and indications for exchange transfusion. Ruys and van Gelderen (1962) did not find such a rise after priming 3 neonates with albumin. Our previous experience of albumin priming in 10 neonates concurred with the findings of the latter workers.

In Hong Kong, many newborn babies are admitted into hospital with high levels of serum bilirubin. Rhesus incompatability is rare (Grimmo and Lee, 1961) and many of these babies do not show evidence of active haemolysis. The serum bilirubin does not rise very rapidly. The effectiveness of phenobarbitone in lowering the serum bilirubin level (Yeung and Field, 1969) and in facilitating the hepatic handling of bromsulphalein in these infants (Yeung and $Y u, 1971$ ) suggests that the hyperbilirubinaemia may be the result of reduced glucuronyl transferase activity during the early neonatal period. These patients, therefore, provide an ideal situation for studying the effects of albumin administration on the distribution of bilirubin in the body.

The present study was undertaken to delineate the changes occurring during the first few hours after albumin administration and the effect of the latter on exchange transfusion so that more rational use may be made of albumin in the management of neonatal hyperbilirubinaemia.

\section{Material and Methods}

Twenty-seven term infants between 3 and 14 days of age, with serum bilirubin levels between 13.5 and $39.5 \mathrm{mg} / 100 \mathrm{ml}$ and no known haemolytic disease, were selected for this study. They were all screened for rhesus and ABO group incompatibilities, red blood cell G6PD and pyruvate kinase deficiencies, direct Coombs test, $\mathrm{Hb}$, packed cell volume, and reticulocyte count.

The study was divided into two parts. The first part was designed to study the changes occurring during the first few hours after albumin priming: 7 babies were included in this study. Each was given salt-poor human albumin (Cutter) as a $10 \%$ solution via an umbilical venous catheter at a dose of $1.75 \mathrm{~g} / \mathrm{kg}$ body weight over a period of approximately 2 minutes. Blood samples were taken immediately before the infusion, 5 minutes after the infusion, and thereafter at halfhourly or hourly intervals for as long as the circumstances would permit. The blood samples were divided into 2 portions: one in EDTA bottles for estimations of $\mathrm{Hb}$ and packed cell volume, and the other in plain bottles with light-proof wrappings to extract serum for total bilirubin, serum albumin and $2\left(4^{\prime}\right.$-hydroxyazobenzene) benzoic acid (HBABA) binding capacity.

The second part of the study was to determine the effect of albumin administration on subsequent exchange transfusion: 20 babies were included in this study; 7 were given albumin as above approximately 3 hours before the exchange transfusion (Group A); 7 received a simple exchange transfusion without the use of albumin (Group B). Six received no albumin before the exchange transfusion, but had $1.5 \mathrm{~g}$ albumin added to every $100 \mathrm{ml}$ of the donor's blood. The albuminenriched donor's blood was then used for exchange transfusion (Group C). No attempt was made to render the 3 groups comparable as regards birthweight, gestational age, etc. However, they were all term infants with birthweight above $2500 \mathrm{~g}$. The only criterion for inclusion in the study was that they did not have a haemolytic disease. A rigid two-volume exchange transfusion was not employed. For these reasons, the efficiency of bilirubin removal by exchange transfusion is expressed as percentage of the theoretical bilirubin clearance from plasma by serial dilution with donor's blood, assuming that no diffusion is taking place. The method of calculation is given below.

Blood samples were taken from the patients before albumin priming (where applicable), before exchange transfusion, and after exchange transfusion. A sample of blood used for exchange transfusion was also taken at the beginning and at the end of the procedure. Heparin was added to the 'waste' blood to prevent clotting. All the blood samples were analysed for $\mathrm{Hb}$ content, packed cell volume, total bilirubin, and HBABA binding capacity.

Total bilirubin was determined spectrophotometrically (Chiamori, Henry, and Golub, 1961). HBABA binding capacity was done according to the method described by Porter and Waters (1966). Serum albumin was measured by the biuret method after salting out with $28 \%$ sodium sulphite. Screening tests for red blood cell glucose-6-phosphate dehydrogenase, and pyruvate kinase deficiencies were carried out using Beutler's fluorescence spot techniques (Beutler, 1966).

\section{Blood and plasma volume changes.}

Plasma volume $(\mathrm{PV})=$ Blood Volume $(\mathrm{BV}) \times(1-$ Haematocrit)

Plasma volume at time $t\left(\mathbf{P V}_{t}\right)$ as per cent original plasma volume $\left(\mathrm{PV}_{\mathrm{o}}\right)=\frac{\mathrm{PV}_{\mathrm{t}}}{\mathrm{PV}_{\mathrm{o}}} \times 100$

If the total circulating red cell volume $(\mathrm{M})$ remains constant,

Then $M=$ Original haematocrit $\left(\mathrm{Hct}_{\mathrm{o}}\right) \times$ original blood volume $\left(\mathrm{BV}_{\mathrm{o}}\right)$

$\begin{aligned} \mathrm{PV}_{\mathrm{o}} & =\mathrm{BV}_{\mathrm{o}}-\mathrm{M} \\ \text { and, } \mathrm{M} & =\text { Haematocrit at time } \mathrm{t}\left(\mathrm{Hct}_{\mathrm{t}}\right) \times \text { Blood }\end{aligned}$ volume at time $t\left(B_{t}\right)$

$\mathrm{PV}_{\mathrm{t}}=\mathrm{BV}_{\mathrm{t}}-\mathrm{M}$

Therefore,

$$
\begin{aligned}
\mathrm{Hct}_{\mathrm{o}} & \times \mathrm{BV}_{\mathrm{o}}=\mathrm{Hct}_{\mathrm{t}} \times \mathrm{BV}_{\mathrm{t}} \\
\mathrm{PV}_{\mathrm{t}} & =\mathrm{BV}_{\mathrm{t}}-\mathrm{BV}_{\mathrm{t}} \times \mathrm{Hct}_{\mathrm{t}} \\
& =\mathrm{BV}_{\mathrm{t}}\left(1-\mathrm{Hct}_{\mathrm{t}}\right) \\
& =\frac{\mathrm{BV}_{\mathrm{o}} \mathrm{Hct}_{\mathrm{o}}}{\mathrm{Hct}_{\mathrm{t}}}\left(1-\mathrm{Hc}_{\mathrm{t}}\right)
\end{aligned}
$$


Expressed as per cent original blood volume,

$$
\begin{aligned}
\mathrm{PV}_{\mathrm{t}} & =\frac{\frac{\mathrm{BV}_{\mathrm{o}} \mathrm{Hct}_{\mathrm{o}}}{\mathrm{Hct}_{\mathrm{t}}}\left(1-\mathrm{Hct}_{\mathrm{t}}\right)}{\mathrm{BV}_{\mathrm{o}}} \times 100 \\
& =\frac{\mathrm{Hct}_{\mathrm{o}}}{\mathrm{Hct}_{\mathrm{t}}}\left(1-\mathrm{Hct}_{\mathrm{t}}\right) \times 100
\end{aligned}
$$

Expressed as per cent original plasma volume,

$$
\begin{aligned}
& \mathrm{PV}_{\mathrm{t}}=\frac{\frac{\mathrm{BV}_{\mathrm{o}} \mathrm{Hc}_{\mathrm{o}}}{\mathrm{Hct}_{\mathrm{t}}}\left(1-\mathrm{Hct}_{\mathrm{t}}\right)}{\mathrm{BV}_{\mathrm{o}}\left(1-\mathrm{Hct}_{\mathrm{o}}\right)}=100 \\
& =\frac{\frac{\mathrm{Hct}_{\mathrm{o}}}{\mathrm{Hct}_{\mathrm{t}}}\left(1-\mathrm{Hct}_{\mathrm{t}}\right)}{\left(1-\mathrm{Hct}_{\mathrm{o}}\right)} \ldots \ldots \ldots
\end{aligned}
$$

\section{Bilirubin.}

Initial intravascular bilirubin mass $\left(\mathrm{TB}_{\mathrm{o}}\right)$

$$
\begin{aligned}
& =\mathrm{PV}_{\mathrm{o}} \times \text { original serum bilirubin } \\
& \text { level }\left(\mathbf{S B}_{\mathrm{o}}\right)
\end{aligned}
$$

Intravascular bilirubin mass at time $t\left(\mathrm{~TB}_{\mathrm{t}}\right)$

$$
\begin{aligned}
& =\mathrm{PV}_{\mathbf{t}} \times \text { serum bilirubin level at } \\
& \text { time } \mathbf{t}\left(\mathrm{SB}_{\mathbf{t}}\right) \\
& =\mathrm{PV}_{\mathbf{O}} \times(\mathrm{A}) \times \mathrm{SB}_{\mathbf{t}}
\end{aligned}
$$

Therefore,

$T B_{t}$ expressed as per cent $T B_{o}$

$$
\begin{aligned}
& =\frac{\mathrm{PV}_{\mathrm{o}} \times(\mathrm{A}) \times \mathrm{SB}_{\mathrm{t}}}{\mathrm{PV}_{\mathrm{o}} \times \mathrm{SB}_{\mathrm{o}}} \times 100 \\
& =\frac{\mathrm{SB}_{\mathrm{t}}}{\mathrm{SB}_{\mathrm{o}}} \times(\mathrm{A}) \times 100
\end{aligned}
$$

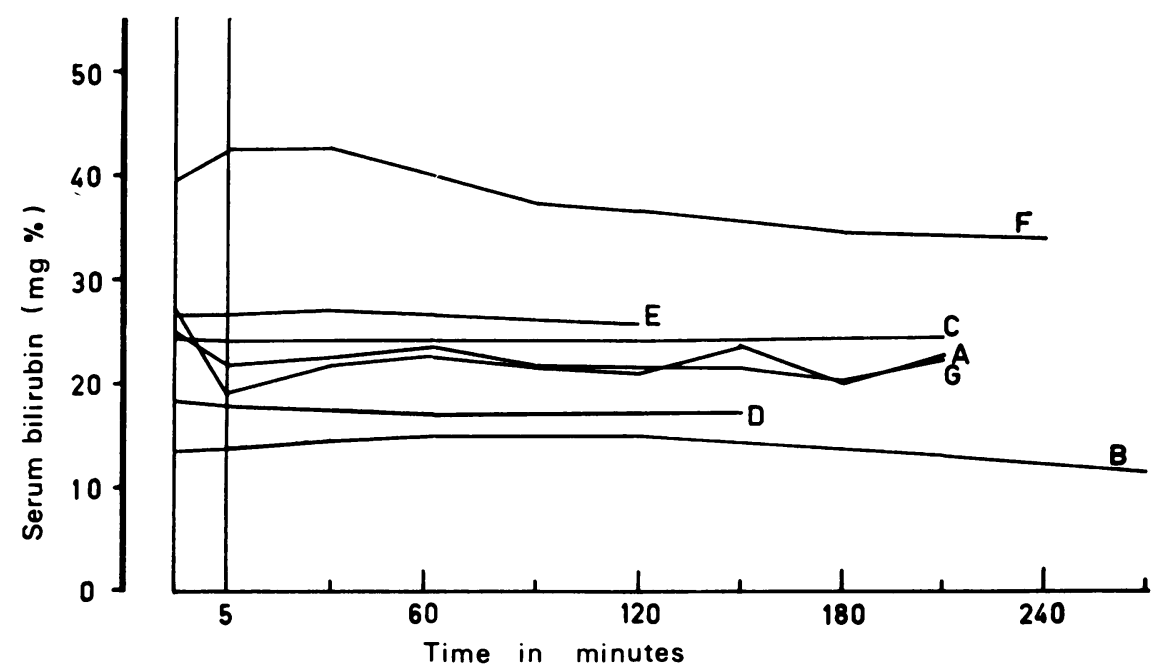

FIG. 1.-Serum bilirubin concentration after administration of albumin in 7 jaundiced neonates. Note variable but usually slight effect on concentration.
HBABA-binding capacity. HBABA-binding capacity per $100 \mathrm{ml}$ plasma is expressed as per cent of $4 \mathrm{~g}$ albumin standard.*

Total intravascular HBABA-binding capacity

$$
=\frac{\text { HBABA-binding capacity } / 100 \mathrm{ml} \text { plasma }}{100} \times \mathrm{PV}
$$

Exchange transfusion. Actual amount of bilirubin removed $\left(\mathrm{TB}_{\mathrm{w}}\right)$

$=$ Volume of blood in waste bottle $\times\left(1-\mathrm{Hct}_{\mathrm{w}}\right) \times \mathrm{SB}_{\mathrm{w}}$

Assuming that no diffusion of bilirubin takes place between the intra- and the extravascular compartments during the course of exchange transfusion, theoretical amount of bilirubin removed $\left(\mathrm{TB}_{\mathrm{th}}\right)$

$=\left[1-\left(\frac{\mathrm{BV}_{\mathrm{o}}-\mathrm{v}}{\mathrm{BV}_{\mathrm{o}}}\right)^{\mathrm{n}}\right] \times \mathrm{BV}_{\mathrm{o}} \times\left(1-\mathrm{Hct}_{\mathrm{o}}\right) \times$ where, $\mathrm{v}=$ volume of each syringeful of blood exchanged - volume of the dead space in the catheter $\mathbf{n}=$ number of syringefuls of blood exchanged $\mathrm{SB}_{\mathrm{D}}=$ serum bilirubin level of donor's blood Original blood volume was taken to be $85 \mathrm{ml} / \mathrm{kg}$ body weight

Efficiency of bilirubin removal $=\frac{\mathrm{TB}_{\mathrm{w}}}{\mathrm{TB}_{\mathrm{th}}} \times 100$

\section{Results}

After albumin priming in the first part of the study, the maximum increase in blood volume in individual patients varied from $15 \%$ to $45 \%$. The peak was usually reached 30 minutes after the

^Sigma Chemical Co. 
administration. The plasma volume remained expanded throughout the period of observation but showed a gradual reduction with time. No untoward effects were observed in the 14 babies so treated in this study and in another 10 babies not included in this study. The serum bilirubin concentration fluctuated only very slightly. It was actually lowered in some patients (Fig. 1). There was an increase in the total intravascular bilirubin, reaching a peak about half an hour after albumin priming (Fig. 2). Thereafter, it showed a gradual decline except in two patients who showed a secondary rise. This corresponded with the changes in the plasma volume.

The total intravascular albumin was much increased after albumin priming (Fig. 3). It then fell gradually suggesting diffusion out of the intravascular compartment. Towards the end of the observation period, the total intravascular albumin was still raised but there was a tendency to level off, indicating that a new equilibrium had been established.

The HBABA-binding capacity, expressed either as per $100 \mathrm{ml}$ plasma or as total intravascular
HBABA-binding capacity, was also raised after albumin priming (Fig. 4). Both tended to level off at a raised level after the first hour. Thus, the reserve binding capacity of the patient's plasma was shown to be increased throughout the period of study.

When the efficiency of exchange transfusion in the 3 groups of babies was compared in the second part of the study, it was lowest in those babies who had been primed with albumin 3 hours before exchange transfusion, and was highest in those who received albumin-enriched donor's blood (Fig. 5). The details are shown in the Table. The mean expansion of plasma volume at 3 hours after albumin priming was calculated to be $+50 \%$ (range: $+17 \%$ to $+87 \%$ ).

\section{Discussion}

With the type of patient material and within the short time limits of the first part of the study, it is unlikely that the changes encountered were due to factors of bilirubin production or removal. The results are therefore most likely to be due to

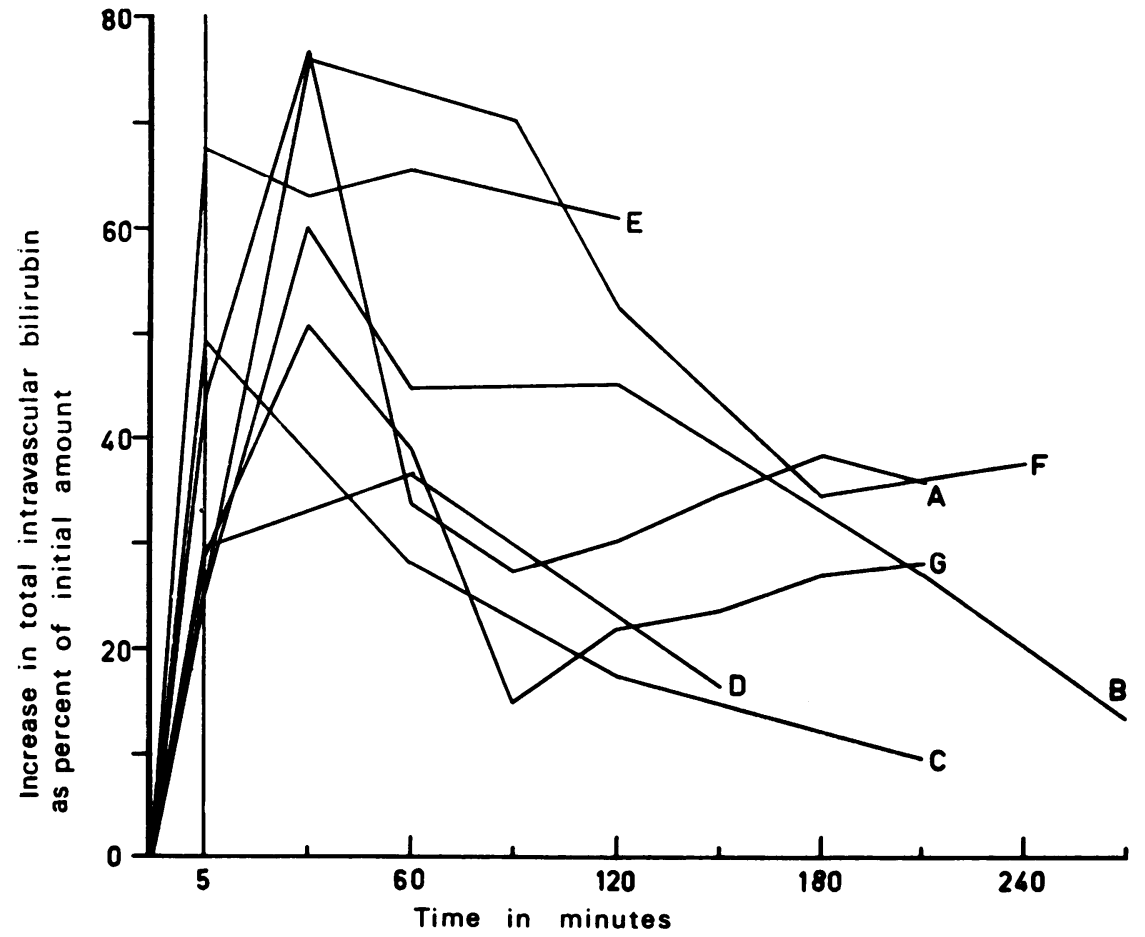

FIG. 2.-Percentage increase in total intravascular bilirubin after administration of albumin in 7 jaundiced neonates. Note initial rise, followed by fall. 


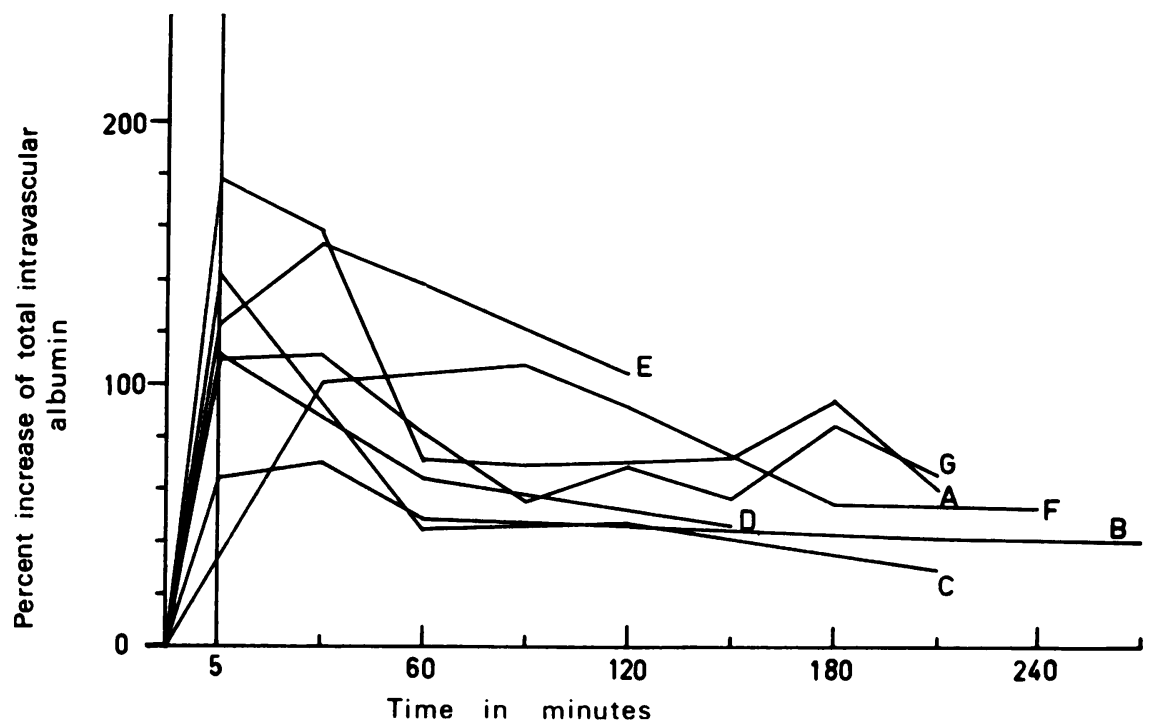

FIG. 3.-Changes in total intravascular albumin after administration of albumin in 7 jaundiced neonates.

redistribution of bilirubin in the various body compartments.

At the end of the observation period, there was a net gain of bilirubin within the intravascular compartment, together with an increased HBABAbinding capacity, expressed either in terms of total intravascular albumin or in terms of per unit volume of plasma. The shift of bilirubin into the intravascular compartment resulted in a corresponding reduction of extravascular bilirubin. With increased reserve binding capacity of the intravascular albumin, the toxic diffusible fraction of bilirubin can be expected to be correspondingly reduced.

In these 7 patients, the serum bilirubin level did not vary to any great extent after albumin priming.

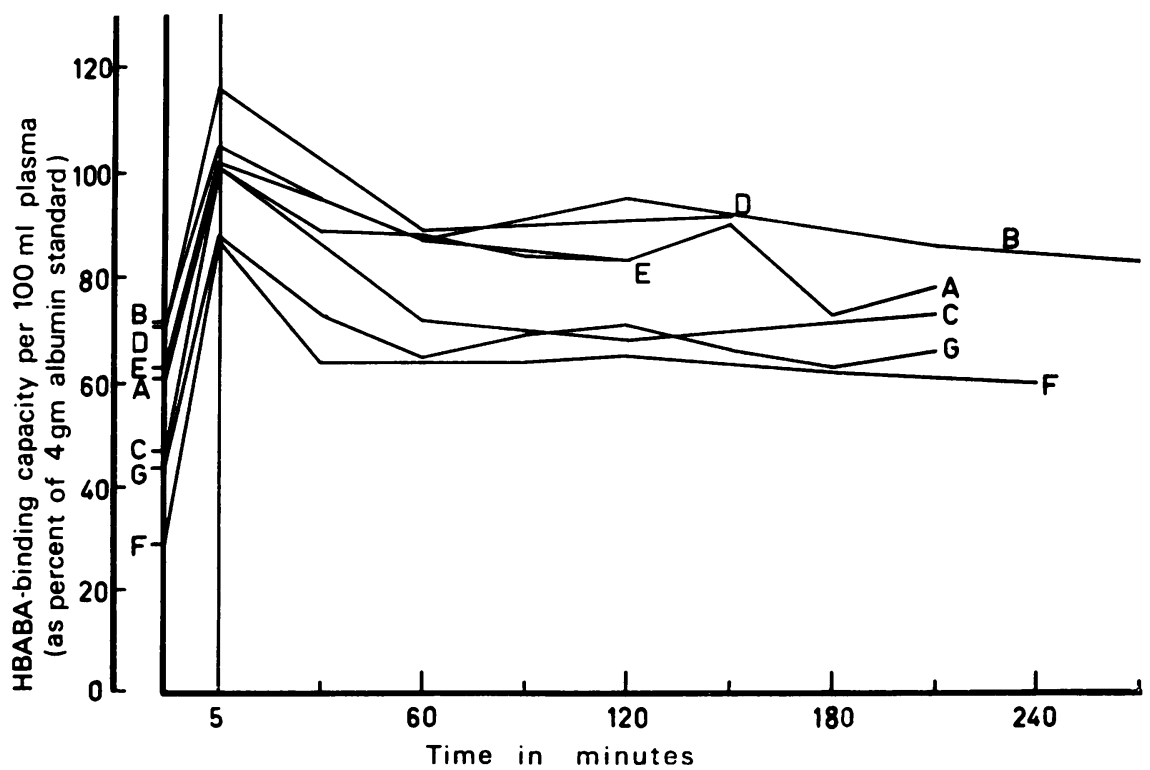

FIG. 4.-Changes in HBABA-binding capacity per $100 \mathrm{ml}$ plasma after administration of albumin in 7 jaundiced neonates. 


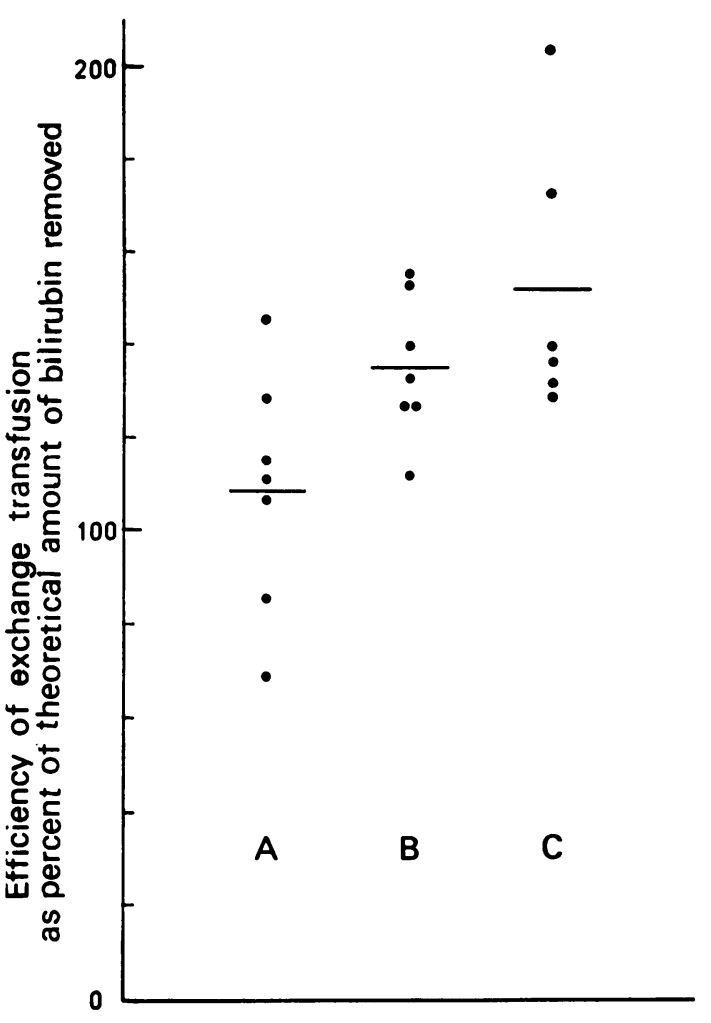

FIG. 5.-Comparing the efficiency of exchange transfusion in 3 groups of patients: $A=$ those who had albumin priming 3 hours before exchange transfusion; $B=$ those who received a simple transfusion without albumin; $C=$ those who received exchange transfusion using albumin-enriched donor's blood. The cross bars represent the mean value for each group.

This is contrary to the conclusions of Odell et al. (1962) but is in agreement with the findings of Ruys and van Gelderen (1962). The different results obtained may be explained by the greater expansion of plasma volume in our patients. It is noteworthy that in the series of Odell et al. (1962), 3 of their patients also had a decrease in serum bilirubin level after albumin administration. The mean expansion of plasma volume in their series, as calculated from the data available, was $+22 \%$ (range: 0 to $+43 \%$ ).

With the relatively large dose of albumin employed in these babies, there was a very significant increase in blood volume. This is undesirable in babies who are already hypervolaemic. We have not encountered any ill effects in our babies but would not recommend the use of albumin priming in any baby who is severely anaemic or has impaired cardiac function. When a $10 \%$ solution of albumin is used, as in our patients, the expansion in plasma volume is greater than when a $25 \%$ solution is used. This suggests that the more concentrated albumin solution is to be preferred for priming purposes.

The efficiency of bilirubin removal by exchange transfusion is dependent on at least 2 factors: the relative size of the patient's blood volume versus the amount of blood used for exchange transfusion, and the movement of bilirubin from the extravascular into the intravascular compartment during the procedure. The latter is related in part to the availability of binding sites on the intravascular albumin, and in part to the fixation of bilirubin to the tissue (Odell, 1970). Early priming with albumin results in an expanded blood volume and allows time for the escape of a large amount of the albumin and bilirubin gained from the extravascular pool. The result is a slightly decreased efficiency as shown by group A patients in the second part of the study. Comley and Wood (1968) also found no significant difference in bilirubin clearance between simple exchange transfusion and albumin priming 1 to 6 hours before the procedure, though their babies were all given a 2-volume exchange transfusion. Their results were slightly in favour of albumin priming, but this may be explained by the variable time interval before the exchange transfusion was carried out in their study. Decreasing efficiency with increasing time interval between albumin priming and exchange transfusion can also be demonstrated from the data of Odell et al. (1962), when the bilirubin removed per $\mathrm{kg}$ body weight has been corrected to a standard 'pre-exchange serum bilirubin level' and a standard 'percent of body weight exchanged'.

When albumin is added during exchange transfusion, the rapid influx of bilirubin more than compensates for the effect of the expanded blood volume, so that more efficient bilirubin removal is achieved as shown in Group C. Here our result is also consistent with the findings of Comley and Wood (1968) in their Group II patients who received a total of about $20 \mathrm{~g}$ albumin at intervals during exchange transfusion. They employed a much larger amount of albumin and therefore obtained a correspondingly higher bilirubin clearance.

Thus it may be concluded that albumin administration is effective in offering immediate and shortterm protection against bilirubin toxicity. If albumin is intended for increasing the removal of bilirubin during exchange transfusion, it seems more logical to administer it together with donor's blood. If, on the other hand, albumin is used 
TABLE

Efficiency of Bilirubin Removal in Three Groups of Patients

(see legend to Fig. 5)

\begin{tabular}{|c|c|c|c|c|c|c|c|c|}
\hline & \multirow{2}{*}{ No. } & \multirow{2}{*}{$\begin{array}{l}\text { Blood } \\
\text { Volume } \\
\text { (ml) }\end{array}$} & \multirow{2}{*}{$\begin{array}{c}\text { Per } \\
\text { Cent } \\
\text { Exchange }\end{array}$} & \multirow{2}{*}{$\begin{array}{l}\text { Initial Serum } \\
\text { Bilirubin } \\
(\mathrm{mg} / 100 \mathrm{ml})\end{array}$} & \multirow{2}{*}{$\begin{array}{c}\text { 'Waste' } \\
\text { Blood } \\
(\mathrm{ml})\end{array}$} & \multicolumn{2}{|c|}{ Bilirubin Removal } & \multirow{2}{*}{$\begin{array}{l}\text { Efficiency } \\
\text { of Bilirubin } \\
\text { Removal }\end{array}$} \\
\hline & & & & & & Actual & Theoretical & \\
\hline Group A & $\begin{array}{l}1 \\
2 \\
3 \\
4 \\
5 \\
6 \\
7\end{array}$ & $\begin{array}{l}228 \\
275 \\
228 \\
271 \\
250 \\
236 \\
220\end{array}$ & $\begin{array}{l}84 \\
78 \\
82 \\
75 \\
78 \\
81 \\
91\end{array}$ & $\begin{array}{l}24 \cdot 0 \\
19 \cdot 5 \\
22 \cdot 6 \\
24 \cdot 5 \\
17 \cdot 2 \\
26 \cdot 2 \\
24 \cdot 2\end{array}$ & $\begin{array}{l}400 \\
390 \\
380 \\
370 \\
360 \\
380 \\
500\end{array}$ & $\begin{array}{l}24 \cdot 7 \\
20 \cdot 0 \\
24 \cdot 8 \\
28 \cdot 6 \\
29 \cdot 9 \\
55 \cdot 3 \\
32 \cdot 7\end{array}$ & $\begin{array}{l}28 \cdot 9 \\
28 \cdot 8 \\
22 \cdot 3 \\
24 \cdot 9 \\
23 \cdot 3 \\
38 \cdot 0 \\
30 \cdot 7\end{array}$ & $\left.\begin{array}{r}85 \cdot 5 \\
69 \cdot 2 \\
111 \cdot 2 \\
114 \cdot 9 \\
128 \cdot 3 \\
145 \cdot 5 \\
106 \cdot 5\end{array}\right\}(\mathrm{m}=108 \cdot 7)$ \\
\hline Group B & $\begin{array}{r}8 \\
9 \\
10 \\
11 \\
12 \\
13 \\
14\end{array}$ & $\begin{array}{l}330 \\
338 \\
330 \\
310 \\
340 \\
336 \\
266\end{array}$ & $\begin{array}{l}71 \\
78 \\
75 \\
74 \\
67 \\
70 \\
85\end{array}$ & $\begin{array}{l}17 \cdot 5 \\
27 \cdot 0 \\
20 \cdot 1 \\
21 \cdot 7 \\
22 \cdot 0 \\
23 \cdot 6 \\
17 \cdot 0\end{array}$ & $\begin{array}{l}400 \\
500 \\
440 \\
400 \\
360 \\
390 \\
470\end{array}$ & $\begin{array}{l}23 \cdot 0 \\
70 \cdot 7 \\
44 \cdot 0 \\
31 \cdot 6 \\
35 \cdot 3 \\
43 \cdot 3 \\
32 \cdot 7\end{array}$ & $\begin{array}{l}20 \cdot 5 \\
45 \cdot 4 \\
33 \cdot 1 \\
24 \cdot 9 \\
27 \cdot 8 \\
28 \cdot 3 \\
23 \cdot 3\end{array}$ & $\left.\begin{array}{l}112 \cdot 2 \\
155 \cdot 7 \\
132 \cdot 9 \\
126 \cdot 9 \\
127 \cdot 0 \\
153 \cdot 0 \\
140 \cdot 0\end{array}\right\}(\mathrm{m}=135 \cdot 4)$ \\
\hline Group C & $\begin{array}{l}15 \\
16 \\
17 \\
18 \\
19 \\
20\end{array}$ & $\begin{array}{l}275 \\
300 \\
262 \\
336 \\
336 \\
296\end{array}$ & $\begin{array}{l}78 \\
86 \\
86 \\
74 \\
78 \\
76\end{array}$ & $\begin{array}{l}20 \cdot 8 \\
22 \cdot 2 \\
18 \cdot 5 \\
17 \cdot 0 \\
20 \cdot 5 \\
21 \cdot 3\end{array}$ & $\begin{array}{l}400 \\
590 \\
490 \\
440 \\
500 \\
450\end{array}$ & $\begin{array}{l}34 \cdot 1 \\
47 \cdot 8 \\
35 \cdot 5 \\
40 \cdot 6 \\
46 \cdot 5 \\
29 \cdot 8\end{array}$ & $\begin{array}{l}26 \cdot 4 \\
35 \cdot 0 \\
17 \cdot 4 \\
23 \cdot 5 \\
38 \cdot 1 \\
27 \cdot 9\end{array}$ & $\left.\begin{array}{l}129 \cdot 2 \\
136 \cdot 6 \\
204 \cdot 0 \\
172 \cdot 8 \\
132 \cdot 0 \\
140 \cdot 0\end{array}\right\}(m=152 \cdot 4)$ \\
\hline
\end{tabular}

Difference between the means of:

Groups A and B ...t $=2 \cdot 375, \mathrm{v}=12, \mathrm{P}<0.05$

Groups $B$ and $C \ldots t=1 \cdot 297, v=11,0.20<P<0.30$

Groups $A$ and $C \ldots t=2 \cdot 853, v=11, P<0.02$

mainly for its initial protective function, then the sooner the exchange transfusion can be carried out after the priming, the greater will be its effect on the efficiency of bilirubin removal.

We would like to thank Professor C. E. Field for her keen interest in this study, Professor G. M. Kneebone for reading the manuscript, and the staff of the Department of Paediatrics for their co-operation in complying with the protocol.

\section{REFERENCBS}

Beutler, E. (1966). A series of new screening procedures for pyruvate kinase deficiency, glucose-6-phosphate dehydrogenase deficiency, and glutathione reductase deficiency. Blood, 28, 553.

Burnstine, R. C., and Schmid, R. (1962). Solubility of bilirubin in aqueous solutions. Proceedings of the Society for Experimental Biology and Medicine, 109, 356.

Chiamori, N., Henry, R. J., and Golub, O. J. (1961). Studies on the determination of bile pigments. II. Spectrophotometric determination of bilirubin and hemoglobin in serum. Clinica Chimica Acta, 6, 1.

Comley, A., and Wood, B. (1968). Albumin administration in exchange transfusion for hyperbilirubinaemia. Archives of Disease in Childhood, 43, 151.

Diamond, I. (1969). Bilirubin binding and kernicterus. Advances in Pediatrics, 16, 99.

Diamond, I., and Schmid, R. (1966). Experimental bilirubin encephalopathy. The mode of entry of bilirubin-14C into the central nervous system. Fournal of Clinical Investigation, 45, 678.

Grimmo, A. E. P., and Lee, S. K. (1961). A survey of blood groups in Hong Kong Chinese of Cantonese origin. Oceania, 31, 222.
Harris, R. C., Lucey, J. F., and MacLean, J. R. (1958). Kernicterus in premature infants associated with low concentrations of bilirubin in the plasma. Pediatrics, 21, 875.

Kitchen, W. H., Krieger, V. I., and Smith, M. A. (1960). Human albumin in exchange transfusion. Fournal of Pediatrics, 57, 876.

Lucey, J. F. (1966). Comment on article 'Kernicterus: Revised Concepts of Pathogenesis and Management' by I. Diamond. Pediatrics, 38, 545.

Odell, G. B. (1959a). The dissociation of bilirubin from albumin and its clinical implications. Fournal of Pediatrics, 55, 268.

Odell, G. B. (1959b). Studies in kernicterus. I. The protein binding of bilirubin. Journal of Clinical Investigation, 38, 823 .

Odell, G. B. (1970). The distribution and toxicity of bilirubin. E. Mead Johnson Address, 1969. Pediatrics, 46, 16.

Odell, G. B., Cohen, S. N., and Gordes, E. H. (1962). Administration of albumin in the management of hyperbilirubinemia by exchange transfusions. Pediatrics, 30, 613.

Ostrow, J. D., and Schmid, R. (1963). The protein-binding of Cl4-bilirubin in human and murine serum. Fournal of Clinical Investigation, 42, 1286.

Porter, E. G., and Waters, W. J. (1966). A rapid micromethod for measuring the reserve albumin binding capacity in serum from newborn infants with hyperbilirubinemia. Fournal of Laboratory and Clinical Medicine, 67, 660.

Ruys, J. H., and van Gelderen, H. H. (1962). Administration of albumin in exchange transfusion. Fournal of Pediatrics, 61, 413.

Yeung, C. Y., and Field, C. E. (1969). Phenobarbitone therapy in neonatal hyperbilirubinaemia. Lancet, 2, 135.

Yeung, C. Y., and Yu, V. Y. H. (1971). Phenobarbitone enhancement of bromsulphalein clearance in neonatal hyperbilirubinemia. Pediatrics, 48, 556.

Correspondence to Dr. Y. C. Tsao, Department of Paediatrics, Queen Mary Hospital, Hong Kong. 